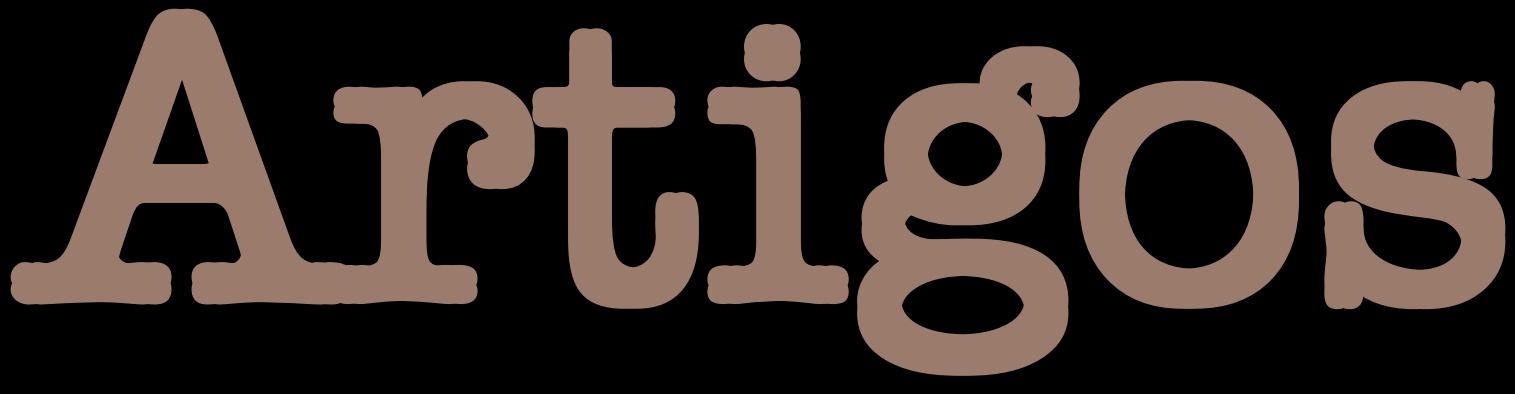

O sertão-mundo de Guimarães Rosa Maria Célia Leonel \&o José Antonio Segatto

Sexualidade e Gênero - As metáforas do biopoder Rosana Ribeiro Patricio

Arte autoetnográfica Heidrun Krieger Qlinto

As flihas de Pandore as mulheres, o tempo a cultura Ivia Alves

O comparatista ClEudio Veiga Cid Seixas

Critérios para Publicação

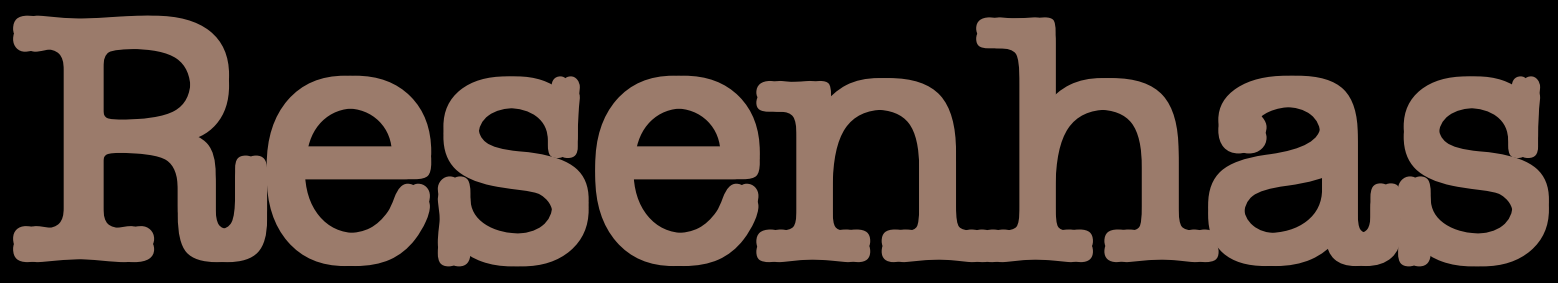




\section{O comparatista Cláudio Veiga}

Cid Seixas, UFBA / UEFS

Há quase meio séculos um conceituado professor de Língua e Literatura Francesas lançava o livrinho Castro Alves, guia da catedral, com o selo da Livraria Universitária. Trata-se do mestre Cláudio Veiga, ex-presidente da Academia de Letras da Bahia, função que ocupou por algumas décadas, com o mesmo zelo e espírito empreendedor dos primeiros anos.

Mas não se tratava de um iniciante, antes ele havia publicado teses e estudos universitários sobre Pascal (1954, 1957 e 1959), além de dois livros didáticos, Vestibular de Francês (1964) e Gramática Nova do Francês (1965).

Com aquela nova publicação o ensaísta Cláudio Veiga consolidava um espaço que vinha conquistando, aos poucos, junto ao público situado para além dos muros da Universidade. Com o passar do tempo, as obras foram se sucedendo uma às outras e a audiência se ampliando da Bahia para o mercado editorial brasileiro, através de publicações pelas mais importantes editoras do país. Nos seus quase 80 anos, o ensaísta só fez crescer em quantidade e em qualidade, continuando produtivo e inquieto, brindando o público culto com ensaios e livros vindos a lume com certa regularidade.

Mas o que teria levado o profícuo catedrático e titular aposentado da Ufba a preparar uma nova edição de Castro Alves, guia da catedral tanto tempo depois? Teria sido apenas o desejo de atingir novos leitores? Essa segunda edição, com o selo da GRD, editora nascida na Bahia no final dos anos 60 e depois transferida para São Paulo, tem sobre a primeira edição a vantagem de apresentar as ilustrações a cores. São 34 fotografias panorâmicas ou de detalhes da Catedral Basílica de Salvador que dialogam com o texto ensaístico do autor e, principalmente, com o poema "Jesuítas", de Castro Alves.

MONOGRAMA - Atento a comparações e análises, o ensaísta e mestre de sucessivas gerações atribui o fato da Catedral estar presente na memória do poeta por ter sido a capela do antigo colégio da Companhia de Jesus. Assim, empreende a leitura de cada estrofe do poema, buscando relacionar suas imagens com as imagens do templo que fez fotografar para estabelecer o cotejo com os versos castroalvinos.

Veja-se a passagem seguinte de "Jesuítas": "E o Niágara ia contar aos mares... / E o Chimborazo arremessava aos ares / O nome do Senhor!" Cláudio Veiga chama atenção para a relação entre esta referência condoreira ao nome de Cristo à constante repetição do monograma jesuítico, com a abreviatura do nome de Jesus em grego: IHS. As ilustrações selecionadas para o livro revelam vários pontos da Catedral em que a insígnia aparece com destaque e retrabalhada com diferentes concepções plásticas em que as letras do nome de Jesus formam o único elemento constante. 
A foto do teto da sacristia, com o monograma esculpido em metal dourado e projetado como uma luminária solar, é a mais evidente sugestão da seqüência poética "arremessava aos ares o nome do Senhor". A leitura comparativa proposta pelo professor Cláudio Veiga tem o condão de investir o olhar do leitor ou do visitante do templo de uma perspectiva condoreira ou hiperbólica diante da visão monumental da composição arquitetônica que extasia os sentidos num turbilhão de sinestesias desencadeadas pela argúcia da descoberta exegética do mestre comparatista.

Fiel à tradição francesa que atribui à crítica a função de ler a obra e guiar as possíveis leituras seguidas pelo público, o ensaísta alcança o alvo com pleno domínio dos objetos arrolados. Se, por um lado, ganhou notoriedade no Brasil um tipo de leitura crítica que remete menos ao texto artístico e mais às especulações teóricas de mais recente conformação, por outro lado, a leitura de empenho hermenêutico, a exemplo da buscada por Cláudio Veiga, constitui o modo mais adequado de formar e consolidar um público leitor no país.

HUMILDADE - Enquanto a inteligência universitária mais atual utiliza o texto literário como pretexto para suas cogitações e como exercício prático para compreender formulações teóricas ainda não resolvidas ou dominadas pelo pesquisador, aquele que precisa de indicadores de caminho permanece órfão de um guia que lhe conduza pelas sendas mais intricadas das obras literárias.

Daí o distanciamento cada vez maior entre o leitor e a produção resultante da pesquisa universitária. Parte dessa pesquisa chega ao paroxismo de constituir objeto de interesse apenas para um pequeno grupo próximo aos seus formuladores. Daí a cada vez mais preocupante redução do número de exemplares das revistas e dos livros acadêmicos.

Uma ensaística menos empenhada em decifrar a esfinge da multiplicidade de novas teorias críticas e mais comprometida com o descerramento ou a interpretação da obra literária, de modo a atrair a atenção do público leitor, teria um importante papel a desempenhar nos dias atuais. Foi isso que mestres europeus procuraram fazer com obstinada competência, investindo seus alunos na função de leitor. É esse papel docente que Cláudio Veiga faz questão de exercer com humildade e paciência. E é esse mesmo papel que ele atribui a Castro Alves quando aponta no poema "Jesuítas" a função de guia da Catedral. Aí, uma obra de arte empenha-se na leitura de outra obra de arte, estabelecendo um diálogo dos mais frutíferos.

Trata-se, portanto, de comparação de séries artísticas diversas; de um lado, a série literária, do outro lado, a série pictórica. Cláudio Veiga compara passagens do poema de Castro Alves com altares, teto, paredes e outros espaços da Catedral, aproximando discursos em si tão diversos na aparência.

Desde esse livrinho que em breve completará meio século de concebido, o professor Cláudio Veiga segue o curso das comparações necessárias ao conhecimento de objetos de natureza divergente até formular os seus mais recentes e bem recebidos estudos de literatura comparada. Aí, talvez, a resposta à indagação do que teria levado o autor a preparar uma nova edição do emblemático Castro Alves, guia da catedral, mais de quatro décadas depois: - a sua condição de livro seminal ou de projeto guia do trajeto comparatista de Cláudio Veiga. 